\title{
Business model metrics: an open repository
}

\author{
Marikka Heikkilä ${ }^{1} \cdot$ Harry Bouwman ${ }^{2}$. \\ Jukka Heikkilä $^{1}$ - Sam Solaimani ${ }^{3}$ - Wil Janssen ${ }^{4}$
}

\begin{abstract}
Development of successful business models has become a necessity in turbulent business environments, but compared to research on business modeling tools, attention to the role of metrics in designing business models in literature is limited. Building on existing approaches to business models and performance measurement literature, we develop a generic open repository of metrics related to core business model concepts. We validate and assess the practical value of the repository based on four e-Business model cases. The repository can be utilized in designing business models, specifically for networked enterprises. It is neither complete nor universally applicable, but needs adjustment with each design. Ultimately, with this paper, we hope measurement will become an integral part of the business model innovation discussion.
\end{abstract}

Keywords Business model · Innovation · Metrics · Repository · Performance measure $\cdot$ Design cases · e-Business

\section{Introduction}

Business models (BMs) have received great interest from both academics and professionals since the rise of e-Business and other new ways of doing business with the help of ICT and Internet (Osterwalder and Pigneur 2002). In 2004, the concept Business Model led to 5,300,000 hits in Google, and 10 years later the figure is more

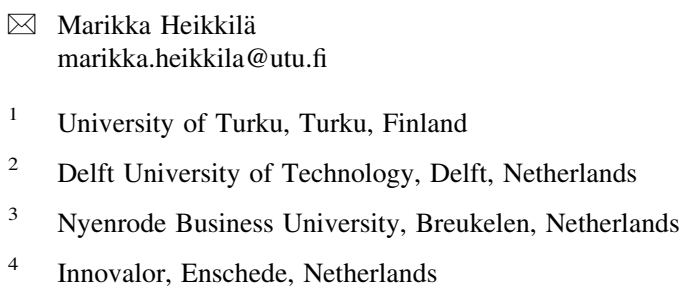


than a hundredfold. Existing literature focuses largely on BM concepts and tools for innovating BMs, whereas less attention has been paid to methods for evaluating BM designs. Even though some BM methods pay attention to financial and investment metrics, non-financial aspects such as technology are seldom measured (Afuah and Tucci 2003; Daas et al. 2013; Gordijn and Akkermans 2001). There is a clear need for research combining evaluation metrics with BM, especially within networked environments (Busi and Bititci 2006; Ferreira et al. 2012; Voelpel et al. 2006).

We contribute to existing BM literature by addressing the measurable performance indicators (metrics). Instead of ex-post quantitative analyses, we are interested in the utilization of metrics in designing BMs. Designing artifacts like products, services, processes or BMs most often lacks well defined metrics that meet strategic or operational objectives. Our viewpoint is that rigorous BMs can be achieved by aligning generic, qualitative BM design statements with metrics and quantifiable objectives.

Furthermore, we explicitly take into account networked organizational settings or ecosystems. Current BM literature focuses predominantly on individual firms, while contemporary BMs, not the least so in e-Business, can be characterized as networks of organizations working together in an activity system (Zott and Amit 2010). Hence, analyzing operational issues and interdependencies between organizations is an essential part of business modeling. The value network-a dynamic network of legally independent, collaborating, and sometimes competing actors who intend to offer a specific service, and in which tangible and intangible value exchanges take place between the actors (De Reuver and Bouwman 2012) — is the unit of analysis in this article.

Building upon the early work of Dubosson-Torbay et al. (2002) and Bouwman and Van den Ham (2003) and responding to the research agenda involving performance measurement for collaborative BMs proposed by Busi and Bititci (2006), we argue that metrics are useful to quantitatively assess or measure various elements of BMs, and have a pragmatic value when designing and implementing BMs. The innovation, design and implementation of BMs in networked environments can be more focused and effective when clear quantitative objectives are formulated in business modeling to steer design and implementation process, also suggested by McGrath (2010). Therefore, in this paper we synthesize from the previous literature a repository of metrics that can be utilized in the design and implementation of BMs. It advocates the idea of BM decisions to be measured in order to bring the high-level BM ideas in sync with strategic objectives and operational reality "that influence the critical dimensions of performance for a firm" (McGrath 2010, p. 252).

To summarize, the objective of this paper is:

to develop an open repository of relevant metrics that can be used in the design and analysis of BMs applicable within individual or networked enterprises.

To achieve the objective, the paper is structured as follows. First, we discuss the concepts of BMs and performance metrics. Next, influenced by the previous literature we present a repository of BM metrics and evaluate its practical usability 
on the basis of four cases. Finally, we present the conclusions and possible avenues for the use of metrics in BM design projects and cases and future research, with a focus on the development of explanatory models.

\section{Business Model literature}

Originating from business informatics, the concept of BM became widely used with the establishment of the Internet and e-Commerce (Wirtz 2011). It was later adopted in strategic management and technology and innovation management literature (Lambert and Davidson 2013; Zott et al. 2011). Since then, academic literature on BMs has expanded rapidly, focusing on definitions, components and elements, ontologies and concepts (e.g., Afuah and Tucci 2003; Al-Debei and Avison 2010; Bouwman and Van den Ham 2003; Bouwman et al. 2008; El Sawy and Pereira 2013; Gordijn et al. 2000; Osterwalder and Pigneur 2002) and, more recently, on BMs and strategy (Casadesus-Masanell and Ricart 2010; Hedman and Kalling 2003; Teece 2010; Zott and Amit 2008, 2010) and on BM design and tooling for innovating and redesigning services (Bouwman et al. 2012; De Reuver et al. 2013; Fritscher and Pigneur 2011; Heikkilä and Heikkilä 2010, 2013). At the same time, businesses as well as consultants embraced Osterwalder and Pigneur's (2010) CANVAS model, and as a result, BM thinking found its way into various industries (Al-Debei and Avison 2010).

There are many definitions of BMs and BM ontologies: CANVAS (Osterwalder and Pigneur 2010); the Service Technology Organization and Finance (STOF) model which focuses on customer and network value for service-based BMs (Bouwman et al. 2008); the customer segmentation BM approach CSOFT (Heikkilä et al. 2010); and the all-digital BM approach Visor (El Sawy and Pereira 2013). What all these approaches have in common is that they describe the business logic, the way value is created and captured for customers as well as for the enterprises involved. Customer Value, Product/Service Elements, Organizational, Financials and Technology are common elements in all BM ontologies (Table 1, see also Wirtz 2011). Some scholars use BMs as a blueprint describing the coherence between core BM components, while others take a more transformational view and utilize the concept as a tool to address innovation and change (Demil and Lecocq 2010). We take the latter approach and define a BM as a tool for analyzing the product/service definition and the intended value for a target group, the source of revenue and the resources, organizational and financial arrangements between the involved business actors, including their roles and the division of costs and revenues (Bouwman et al. 2008, p. 33). In line with McGrath (2010) and Johnson et al. (2008), we see Business Modeling as a learning and planning process where BM assumptions are both articulated and tested. Furthermore, in our definition we implicitly assume that a company isn't able to deliver the necessary resources and capabilities all by themselves, but that it relies on resources and capabilities at an arm's length as proposed by the Resource Dependency theory (Salancik and Pfeffer 2003; Wirtz 2011; Zott and Amit 2010). BM research that goes beyond the single firm and focuses on network enterprises points to the importance of process alignment and 
Table 1 Repository of BM performance metrics

\begin{tabular}{|c|c|}
\hline Perspectives & Theme metrics \\
\hline $\begin{array}{l}\text { Customer value } \\
\text { Value uniqueness } \\
\text { Quality }\end{array}$ & $\begin{array}{l}\text { C1. Created customer value (qualitative description): unique; new to } \\
\text { the world; user experience; perceived customer benefit; brand image; } \\
\text { \# of referrals; attraction of media; price, product range and flexibility } \\
\text { of product; regulation-related and non-tangible values } \\
\text { C2. Market segment and market share: e.g., reach and depth of } \\
\text { customer relations; new and repeat business; customer costs; \# of } \\
\text { countries/areas; search costs, communication; sales growth; sales } \\
\text { volume; customer profitability; average revenue per customer } \\
\text { (ARPU); customer lifetime value; profit/revenue per customer } \\
\text { segment/per product; customer loyalty; average order size; } \\
\text { opportunity size } \\
\text { C3. Website-related indicators: e.g., \# of hits; page views; click- } \\
\text { throughs; \# of unique visitors; \# of repeat visitors; \% of online sales } \\
\text { abandoned before completion; \% of customers who have personalized } \\
\text { their interfaces; duration of stay (stickiness); registered users; } \\
\text { conversion rate; cross-sell ratio; channel mix change } \\
\text { (Bouwman 2003; Dubosson-Torbay et al. 2002; Ferreira et al. 2012; } \\
\text { Heikkilä et al. 2014; Johnson et al. 2008; Rayport and Jaworski 2001) }\end{array}$ \\
\hline $\begin{array}{l}\text { Service } \\
\text { Service-related }\end{array}$ & $\begin{array}{l}\text { S1. Service Development life cycles: development time of new service } \\
\text { (concepts); time to first proposal; \# of customer-requested features } \\
\text { added per upgrade } \\
\text { S2. Quality: e.g., conformance to specifications; product/service } \\
\text { performance; availability; reliability; transparency; product/service } \\
\text { defect/failure rates; quality delivery; time between order and receipt } \\
\text { (delivery time service); average time to respond to customer request; } \\
\text { out-of-stock positions; on-time shipments; shipment accuracy; \% of } \\
\text { orders delivered to correct address; packaging quality }\end{array}$ \\
\hline
\end{tabular}

S3. Satisfaction: e.g., service level; SERVQUAL or SERVPERF; satisfaction barometer; \# of customer complaints; level of billing errors; cycle time to respond to customer complaints

S4. Sustainability: viability; loyalty; level of customer churn; customer retention

(Dubosson-Torbay et al. 2002; Eckerson 2009; Edvinsson and Malone 1997; Ghalayini et al. 1997; Heikkilä et al. 2014; Johnson 2010; Johnson et al. 2008; Kaplan and Norton 1992, 1993, 1996; Keegan et al. 1989; Neely et al. 2002; Smith 2006; Tseng et al. 2009; Venkatraman and Ramanujam 1986)

Technology

Applications

Architecture

Hardware

Data

Infrastructure
T1. Architectural complexity: \# of applications; architecture-related indicators; platform-related indicators; cloud-related metrics; time for software and hardware implementation; extensibility

T2. Data complexity: e.g., consolidation of databases; \# of decentralized (customer) databases; data integration; data availability

T3. Interoperability: metrics of interoperability of systems: \% crosssystem collaboration; system and information quality metrics

T4. Accessibility and Up-time: 24-7 availability and downtime; response time; average time to load a page; \# of languages; help desk calls; disaster recovery; mean time between failures; data security/ integrity

(Dubosson-Torbay et al. 2002; Edvinsson and Malone 1997; Ghalayini et al. 1997; Heikkilä et al. 2014; Rayport and Jaworski 2001) 
Table 1 continued

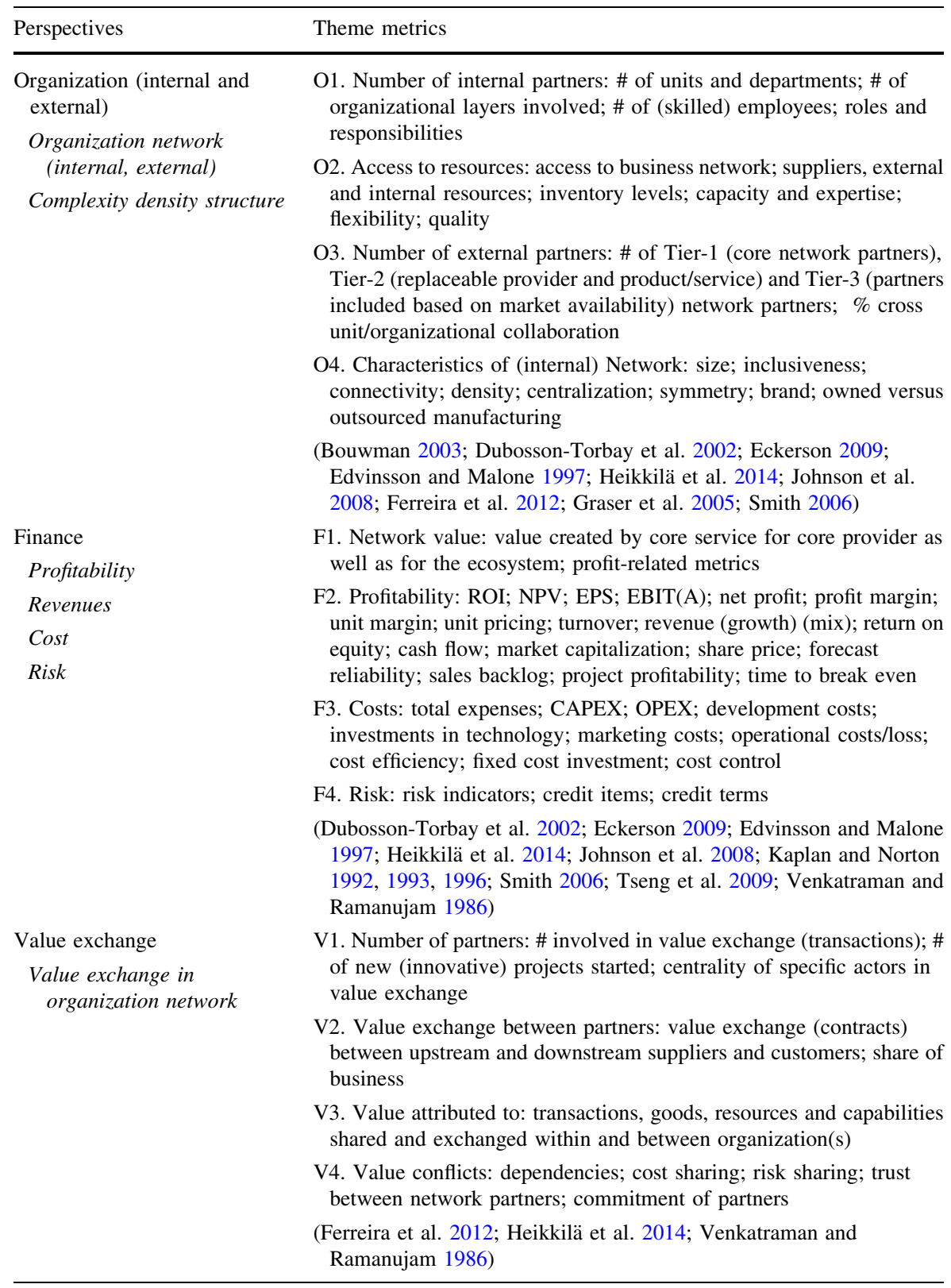


Table 1 continued

\begin{tabular}{|c|c|}
\hline Perspectives & Theme metrics \\
\hline $\begin{array}{l}\text { Information exchange } \\
\text { Information/data/knowledge } \\
\text { availability } \\
\text { Exchange and flow in } \\
\text { organization network } \\
\text { Information system quality }\end{array}$ & $\begin{array}{l}\text { I1. Number of partners: \# involved in data, information and knowledge } \\
\text { exchange; strategic information availability ratio } \\
\text { I2. Data exchange: data, information and knowledge exchange among } \\
\text { core partners (as percentage of total information exchanged); flow } \\
\text { between upstream and downstream suppliers and customers; } \\
\text { information quality; data volumes; information errors or conflicting } \\
\text { information } \\
\text { I3. Information accessibility: \# of access points to external information } \\
\text { systems; \# of shared information systems; \# of dedicated contact } \\
\text { persons on partner's side; shared customer profiles } \\
\text { I4. Knowledge development: suppliers' development; collaboration } \\
\text { (Kaplan and Norton 1992, 1993, 1996; Ferreira et al. 2012; Heikkilä } \\
\text { et al. 2014) }\end{array}$ \\
\hline $\begin{array}{l}\text { Process alignment, internal and } \\
\text { external } \\
\text { Process intensity } \\
\text { Process quality (efficiency, } \\
\text { effectiveness) } \\
\text { Diversity of processes } \\
\text { Process flow }\end{array}$ & $\begin{array}{l}\text { P1. Number of primary processes: (less redundancy); \# of mono/ } \\
\text { bi/multi-directional processes; length of relationship; \# of } \\
\text { (alternative) suppliers; goods, resources and capabilities shared and } \\
\text { exchanged among organizations } \\
\text { P2. Process throughput: average duration; utilization rate; average } \\
\text { response time; average handling time for completed "cases"; } \\
\text { performance according to SLA (bugs, complaints); forecast stability; } \\
\text { JIT; time to market; delayed deliveries (of components) } \\
\text { P3. Process variety: process standardization; \# of process conflicts; } \\
\text { process complexities; dependencies; commonality } \\
\text { (Edvinsson and Malone 1997; Heikkilä et al. 2014; Johnson et al. 2008; } \\
\text { Neely et al. 2002; Tseng et al. 2009) }\end{array}$ \\
\hline
\end{tabular}

the exchange of value, data, information and knowledge within the network (Heikkilä et al. 2005; Solaimani and Bouwman 2012; Solaimani et al. 2013a, b, 2014).

Whereas a large part of BM literature has a strategic management focus (Teece 2010; Johnson et al. 2008; Zott et al. 2011), our interest lies in the design of BMs, especially how metrics could help focus on the improvement of BMs. So far, BM approaches (i.e., methodology, frameworks and tooling) have focused on embedding cost-benefit analysis (see e.g., Gordijn and Akkermans 2001), real options (McGrath 2010), pricing, consumer surplus and willingness to pay (Daas et al. 2013) and financial performance (Tian et al. 2008; Wirtz 2011). Common frameworks like CANVAS, STOF and VISOR currently allow for a limited number of quantitative, mainly financial, metrics to be used in dedicated design tools. Moreover, most of the BM design frameworks are primarily based on subjective qualitative interpretations of the persons using the tools and methods. For instance, CANVAS is a brainstorming tool (Bouwman et al. 2012), and in BM stress testing people use it to select and prioritize uncertainties to trace problematic BM components based on their personal interpretation (Bouwman et al. 2012). By contrast, in CSOFT BM design, key performance indicators are defined for each customer segment and for resource type (business process, application, information, 
hardware and organization) to monitor the process and success of BM implementation. The selection of key performance indicators is agreed upon in facilitated sessions with the top management of the case organization (Heikkilä et al. 2010).

Against this backdrop we can conclude that research remains scant when it comes to support BM design and analyses by metrics other than e-Business-related and financial measures (Bouwman 2003; Bouwman and Van den Ham 2003; Dubosson-Torbay et al. 2002; Heikkilä et al. 2014). Secondly, this raises the question as to which are the relevant metrics to assess feasibility, implementation and viability of BMs on an operational level, i.e., "the metrics that reflect operational activities that influence the critical dimensions (in our view components) of performance for a firm" (McGrath 2010, p. 252).

In this paper, our main contribution is to relate the metrics to the main elements of BM ontologies, i.e., customers, service, technological, organizational and financial issues. This way they are of help in steering and monitoring the process from BM idea to BM implementation and success evaluation. In the next section, we take a closer look at performance measurement literature to form a set of relevant metrics.

\section{Performance measurement literature}

Performance is at the heart of any organization. It is a critical enabler in achieving strategic goals (Harbour 2009). Neely (1994, p. 4) define Performance Measurement (PM) as the "process of quantifying the efficiency and effectiveness of action, a performance measure as a metric used to quantify the efficiency and/or effectiveness of an action, and a performance measurement system as the set of metrics used to quantify both the efficiency and effectiveness of actions." According to Shane (1997), PM is not only an ongoing process designed to assess an organization's performance, but is also used to provide feedback at all levels on how strategic plans are carried out. What is perhaps even more important is the role of selected metrics in communicating the management priorities throughout the entire organization and thus creating a focus for future efforts (Kaplan and Norton 2001).

Existing literature reviews on PM (e.g., Choong 2014; Folan and Browne 2005; Marr 2012; Neely 1994, 2005; Neely et al. 1995, 2000, 2002; Tangen 2004) show an abundance of PM frameworks, approaches and indicators, which can be divided into four categories: PM recommendations, frameworks, systems and interorganizational PM (Folan and Browne 2005). According to Folan and Browne (2005), PM recommendations involve the measures, or structure, of performance measurement. PM frameworks assist in the process of building a performance measurement system by clarifying PM boundaries, dimensions and the relationships among the dimensions (Rouse and Putterill 2003). Folan and Browne (2005) distinguish structural frameworks (i.e., frameworks specifying a typology for performance measure management) from procedural frameworks (i.e., a step-by-step process of developing performance measures from a given strategy). Nevertheless, PM systems are a combination of both structural and procedural frameworks, and also include a number of other enterprise performance management tools, such as innovation or 
sustainability metrics. Finally, the interorganizational PM framework and systems deal with supply chain (i.e., traditional logistics measures) and extended enterprise PM (i.e., metrics for relations with stakeholders, e.g., Neely and Adams 2001; Neely et al. 2002).

PM frameworks have made the greatest impact upon PM literature (Folan and Browne 2005). Frequently discussed frameworks (either structural or procedural) are Balanced Scorecard (Kaplan and Norton 1992), Performance Pyramid (Cross and Lynch 1988), Performance Measurement Framework (Hudson et al. 2001), Performance Prism (Neely et al. 2002), Integrated Performance Measurement Framework (Rouse and Putterill 2003), Wisner and Facett's Framework (Wisner and Fawcett 1991), Performance Measurement Matrix (Keegan et al. 1989), the Sink and Tuttle Model (1989) and Medori and Steeple's framework (2000). For almost any kind of performance, a (set of) metrics can be determined, including the measurement for business process management (e.g., Pritchard and Armistead 1999), knowledge management (e.g., Bose 2004), sustainability (e.g., Epstein and Roy 2001), finance (e.g., Kaplan and Norton 1992), supply chain management (Gunasekaran et al. 2004), project management (Alarcón and Ashley 1996), hospitality management (Chun and Law 2003), service delivery within the public sector (Shane 1998), SMEs (Cocca and Alberti 2010) and non-profit organizations (Kaplan 2001). Generally speaking, metrics are applied at different levels of an organization (Najmi et al. 2005). The strategic level measures the influence of toplevel management decisions, while the tactical level deals with resource allocation and measuring performance against targets, and operational-level measurements and metrics require accurate data to assess the actual results of decisions of low-level managers (Gunasekaran et al. 2004).

When searching literature for performance indicators we found some papers with a focus on networked (or collaborative) enterprises. Voelpel et al. (2006) criticize the Balanced Score Card (Kaplan and Norton 2001) and call for performance measurement frameworks that are suitable for networked business and are more dynamic. Camarinha-Matos and Abreu (2007) propose a set of performance indicators specifically developed for networked enterprises. Kulmala and Lonnqvist (2006) point out that the network's performance measures should reflect the end users' perspective with both financial and non-financial factors. Busi and Bititci (2006) suggest focusing on extended process measures, proactive measures and collaboration measures. Also, Ferreira et al. (2012) suggest collaborative performance measures and Heikkilä et al. (2014) illustrate in a case study how a BMbased set of performance metrics are defined and incorporated into the design of networked BMs.

\section{The tentative repository of metrics for BM}

Since the BM approach and ontologies are already adopted by the industry to innovate new businesses, in this paper we study whether performance metrics can be incorporated into these constructs and thus help the management and designers to design a BM that can actually be implemented. Drawing upon the PM and BM 
literature, we constructed a repository of metrics that can be used to design and implement BMs. The repository was built based on existing performance frameworks and metrics, and on metrics as being discussed in other BM cases. Next, the metrics were classified and clustered by the involved researchers (Miles and Huberman 1994). The classification and clustering criteria were discussed by involved researchers in several rounds on criteria like usability and expressiveness, but also on scientific criteria like reliability and validity, as well as pragmatic criteria, i.e., feasibility to collect or availability of data. For classification and clustering, we decided to utilize the components in existing BM ontologies and extend them by explicitly including network-based activity elements as mentioned by Zott and Amit (2010). Our main focus, however, was on value exchanges among network partners, data information and knowledge sharing, and process alignment (as suggested by Solaimani and Bouwman 2012; Solaimani et al. 2013a, b, 2014). The outcome is a repository of metrics structured according to the common BM elements-Customer, Service, Technical, Organizational, Financial-extended with three extra perspectives on network enterprises-Value exchange, Information exchange and Process alignment-as suggested by BM research on network enterprises:

\section{Customer perspective (C)}

The customer perspective looks at the targeted customer segment (Heikkilä et al. 2010), how customer value is created (Bouwman et al. 2008) and how customer relationships are built (Osterwalder and Pigneur 2010). The aim is to create relevant metrics to represent the fulfillment of the relevant need(s) of customers, to represent the relationship that can or should be established with customers and to quantify the intended value to be created for customers, as well as to follow what customers actually perceive. Candidates for such metrics involve themes of: (1) created customer value; (2) share/coverage of the market segment; and (3) website usage.

2. Service perspective $(\mathrm{S})$

Closely related to the customer perspective is the service perspective. Specifically, with regard to delivering services, a multitude of metrics is available under themes such as: (1) service development; (2) quality; (3) customer satisfaction; and (4) sustainability.

3. Technical perspective $(\mathrm{T})$

Much of the existing BM literature views technology as a core driver and enabler, and grounds for BMs change. Baden-Fuller and Haefliger (2013) discuss the intertwined relationship between technology and other components of the BM. Often technical aspects are grouped together with organizational aspects in BM literature. Osterwalder and Pigneur (2002) for instance discuss both aspects under the label of infrastructure management. Bouwman et al. (2008) and Heikkilä and Heikkilä (2010) in turn view technology as one of the main components in BM. The technical perspective metrics depict performance of ICT, which enables products/services, support operations and collaboration, covering issues like database organization, applications portfolio and platforms, as well as (mobile, wireless) data communication issues through the means of 
enterprise architecting, information and IT infrastructure management. Metrics can be related to themes such as: (1) complexity in the architecture; (2) complexity in databases; (3) interoperability requirements; and/or (4) accessibility and up-time requirements.

4. Organizational perspective $(\mathrm{O})$

The organizational perspective focuses on core resources and capabilities that have to be made available in order to produce the service or product. Resources and capabilities refer to the human and organizational assets within the organization (Janssen et al. 2014) as well as those delivered by other organizations. Typical metrics found in the literature are about the: (1) complexity/variety of internal partners; (2) access to partners; (3) complexity/variety of external partners; and (4) characteristics of network. Specifically, when it comes to suppliers, there is an abundance of operational performance indicators. In our view, relevant indicators are primarily related to network configuration, governance and commitment.

5. Financial perspective $(F)$

Perhaps the most frequently discussed issue in BM and PM literature is that of financial analyses. Both literature streams focus on profitability, the revenue and costs model, as well as pricing schemes and models, investments approaches and risk assessment (Bouwman et al. 2008; Daas et al. 2013; Osterwalder and Pigneur 2002). There is a wide range of metrics that focus on themes of: (1) value of and to the network; (2) profitability; (3) cost, including costs for investments in technology and marketing; and (4) risks.

6. Value exchange (V)

Value exchange can take place within organizational hierarchies, supply chains, or ecosystems. In the latter the value will be exchanged within a market setting, but even then the core providers are engaged in a tight network and operate on a contractual rather than a market transaction basis. As De Reuver and Bouwman (2012) have shown, the value in question is dynamic in nature, and configurations vary in the exploration and exploitation phases of services. Metrics are related to: (1) size of the partner network; (2) contracts; (3) importance; and (4) value conflicts.

7. Information exchange (I)

Information (in both tangible and tacit forms) has to be available at the right time and place, and must be precise and relevant. Information flows can be measured based on data/information volume, and quality/relevance. Examples of metric themes are the: (1) size of the partner network; (2) flow and volume of data and information between actors; (3) information accessibility; and (4) knowledge development.

8. Process alignment $(\mathrm{P})$

Interorganizational process alignment focuses on the operational-level business activities, processes and systems shared between or linking networked organizations. Operational processes make it possible to implement a BM. Process-level metrics include themes such as: (1) number of processes; (2) throughput; and (3) variety. 
In Table 1 we collected metrics found in the literature (Bouwman 2003; Dubosson-Torbay et al. 2002; Eckerson 2009; Edvinsson and Malone 1997; Ferreira et al. 2012; Ghalayini et al. 1997; Graser et al. 2005; Heikkilä et al. 2014; Johnson 2010; Johnson et al. 2008; Kaplan and Norton 1992, 1993, 1996; Keegan et al. 1989; Neely et al. 2002; Rayport and Jaworski 2001; Smith 2006; Tseng et al. 2009; Venkatraman and Ramanujam 1986). The list of metrics is exemplary and in no way exhaustive.

\section{5 e-Business model cases}

We adopted a multiple-case approach to evaluate the proposed repository. The cases as presented are different from ordinary case studies because researchers are actively involved in creating the case (Sein et al. 2011). Design science adopts an actor perspective and is solution-oriented, linking interventions to outcomes (Van Aken and Romme 2009). The result is not only a specific design, but also a design proposition, i.e., a statement with the following logic: "If you want to achieve Y in situation Z, then apply intervention X." In this paper, this high-level proposition can be formulated as follows: If managers or BM designers want to (re)design a BM that is feasible and viable, then the use of a set of metrics will help to focus the BM on the desired strategic outcomes and define relevant performance levels for operational implementations.

Although all known methods for gathering and analyzing data can be used in design science research, in practice, research is case-based, collaborative and interventionist (Van Aken and Romme 2009, p. 10). Typically, design cases follow design phases, using existing design practices and principles (design praxeology, i.e., in our study, business design in general) based on and contributing to existing theories and theories on design (design epistemology, i.e., the domain and process of business modeling for viability and profitability). The final outcomes are artifacts that can be used in practice (articulated BMs; see also Carr 2006). Design cases generate knowledge on how unique artifacts are created in context, while knowledge on the artifact and design process can be reused and theorized.

We examine four cases using existing theories (sometimes labeled as kernel theories, Gregor 2006; or science-based design, Carr 2006; Krippendorff 2006) to explicate the design and research-related tasks throughout various phases of the design process (Verschuren and Hartog 2005; see also Pfeffers et al. 2007; Sein et al. 2011). The phases included: (1) idea generation; (2) requirement elicitation; (3) identification of the solution; (4) development of a prototype; (5) implementation; and (6) evaluation. Sein et al. (2011) specifically add reflection and formalization of learning (i.e., publication of results) as relevant phases.

Our design cases concern organizations that were aiming at radical improvements in their e-Business. Three of the cases are about companies carrying out a major part of their business operations via the Internet, whereas the fourth case is an e-Government case where a regional environmental office was established with supporting ICT architecture. 
The selection of cases was not driven by conceptual or theoretical motives, but motivated more by a replication principle and pragmatic considerations, i.e., availability and commitment. At least one of the authors was involved in the case where we applied different BM ontologies and methods, like the execution of CANVAS (Osterwalder and Pigneur 2010), STOF (Bouwman et al. 2008) and CSOFT (Heikkilä et al. 2010) activities in multiple design phases, but not necessarily in all phases. The focus was on developing and using metrics in major transformations in e-Business models. Three of the cases focus on the guidance of BMs and business logic in implementing enterprise architecture (EA) (design Cases 1, 2 and 4), while one case has a more limited objective, i.e., developing a Decision Support System (DSS) dashboard (design Case 3).

\subsection{Case 1: mobile and internet access provider}

The company is a Mobile and Internet Access Provider of 300 persons that is about to expand its business into new geographic areas, adopting a new core enabling technology in a bid to provide mass-customized services to existing and potential clients. The company's initial decision to move into a new business was inspired by a favorable financial momentum, and especially by a consultant's recommendation of a specific IT solution. However, management wanted to use an alternative approach to see whether the investment would contribute to the desired changes, whether the solution would be compatible with the existing EA and if the solution would turn out to be profitable. One of the expected implications of the planned expansion was a reduction of headcount by $90 \%$ and major changes in the operations. The analysis was carried out together with the steering committee [consisting of Chief Executive Officer (CEO), Chief Financial Officer (CFO), Chief Operating Officer (COO) and Chief Information Officer (CIO)], resulting in merely $13 \mathrm{~h}$ of discussions and brainstorming in three meetings of about 4-5 h. Three of the six stages of the design process were actively explored (Verschuren and Hartog 2005) (see Table 2), primarily making use of CSOFT as a BM approach.

A quality representation of the EA of the company was available, building on core as-is process descriptions. However, management had a hard time interpreting the process descriptions in describing the future BM in a coherent way. Special attention had to be given to clarifying the problem on a conceptual level and at a level of detail that was relevant to the business.

In the brainstorm sessions, it became clear that there were conflicting views on the actual operating models and the importance of the various customer segments and the future means of serving them. A common way to discuss and evaluate feasible and profitable alternatives for future services with management was needed, with sufficient granularity to be handed over for detailed design at a later stage. Before the second meeting (which focused on requirement engineering), BM tools and analytical tools like process modeling were evaluated and CSOFT was found to handle a number of customer segments in a simple communicative manner. The actual meeting started with a strategy discussion during which the generic objectives were reformulated in such a way that the competitive offerings for each customer segment became explicit. CSOFT was used to answer questions like which services 
Table 2 Design and research approach: Case 1

\begin{tabular}{|c|c|c|c|}
\hline Phasing & Task & $\begin{array}{l}\text { Concepts used from kernel } \\
\text { theories }\end{array}$ & Data collection, research \\
\hline Idea & $\begin{array}{l}\text { Discussing initial idea and } \\
\text { earlier solution proposal: } \\
\text { connecting BM with } \\
\text { business strategy targets } \\
\text { and with changes in } \\
\text { operating model } \\
\text { components, specifically } \\
\text { related to processes and } \\
\text { enterprise architecture } \\
\text { Discussion of alternative } \\
\text { solutions instead of the } \\
\text { initial process } \\
\text { improvement proposition }\end{array}$ & $\begin{array}{l}\text { SWOT and Porter's } \\
\text { competitive forces } \\
\text { analysis } \\
\text { Business strategy (mini- } \\
\text { )scenarios with regard to } \\
\text { as-is and to-be } \\
\text { architectural elements of } \\
\text { business, applications, } \\
\text { data and technology }\end{array}$ & $\begin{array}{l}\text { Brainstorming and } \\
\text { consultancy with } \\
\text { steering board (CEO, } \\
\text { CFO, COO and CIO) } \\
\text { Three meetings }\end{array}$ \\
\hline $\begin{array}{l}\text { Requirement } \\
\text { elicitation }\end{array}$ & $\begin{array}{l}\text { Selecting the Business } \\
\text { Model tooling } \\
\text { Formulation of concepts on } \\
\text { a level of detail matching } \\
\text { business requirements }\end{array}$ & $\begin{array}{l}\text { Process analysis } \\
\text { CSOFT }\end{array}$ & $\begin{array}{l}\text { Analyzing proposed initial } \\
\text { solution and articulating } \\
\text { alternative solutions } \\
\text { with the board members }\end{array}$ \\
\hline $\begin{array}{l}\text { Identification } \\
\text { of the } \\
\text { solution }\end{array}$ & $\begin{array}{l}\mathrm{BM} \text { and } \mathrm{BM} \text { metrics } \\
\text { identification }\end{array}$ & $\begin{array}{l}\text { Strategic, business and } \\
\text { operative metrics }\end{array}$ & $\begin{array}{l}\text { Defining metrics } \\
\text { Relation to operating } \\
\text { model components (and } \\
\text { enterprise architecture) }\end{array}$ \\
\hline Prototype & - & & $\begin{array}{l}\text { Urgent interoperability } \\
\text { fixes to customer } \\
\text { databases }\end{array}$ \\
\hline Implementation & BM was implemented & $\begin{array}{l}\text { Roadmap, enterprise } \\
\text { architecture (EA) }\end{array}$ & $\begin{array}{l}\text { Roadmap for platform } \\
\text { change: develop more } \\
\text { detailed EA, generic and } \\
\text { specific operating model } \\
\text { components and road- } \\
\text { mapping for platform } \\
\text { change }\end{array}$ \\
\hline Evaluation & - & - & \\
\hline
\end{tabular}

are offered, which organizations or organizational units would participate in service delivery, how financial arrangements are conceptualized, how revenues are shared and which technology will be used to serve the customers.

Next, metrics were defined for each customer segment. The steering committee was able to define the critical metrics by themselves in a relatively logical and consistent manner. The core requirement was to use a limited but focused set of metrics. The metrics must have a clear focus and be essential, not conflicting. The selected metrics are presented in Table 3.

The case illustrates that it is important to stick to a limited number of high-level metrics for BMs. However, the steering committee preferred to have multiple operational-level metrics covering all perspectives of the BM metrics repository. Keeping and communicating management focus is, however, important in focusing 
Table 3 Metrics in Case 1

\begin{tabular}{|c|c|c|}
\hline Perspectives & Metrics & Theme (from Table 1) \\
\hline $\begin{array}{l}\text { Customer } \\
\text { value }\end{array}$ & $\begin{array}{l}\text { ARPU (exceeding xx €/qtr., all consumer segments) } \\
\text { Market share (objective xx \%, consumer segments: } 1,2,3 \text { ) } \\
\text { Regional coverage (xx \% of full potential in geographical } \\
\text { area, consumer segment: } 3 \text { ) } \\
\text { Conversion rate of contacting ( }>\mathrm{xx} \%)\end{array}$ & $\begin{array}{l}\text { C2: Market segment and } \\
\text { market share } \\
\text { C2. Market segment and } \\
\text { market share } \\
\text { C2: Market segment and } \\
\text { market share } \\
\text { C3: Website-related } \\
\text { indicators } \\
\text { C3: Website-related } \\
\text { indicators }\end{array}$ \\
\hline Service & $\begin{array}{l}\text { Delayed deliveries }(<\mathrm{X} \%) \\
\text { Time to market (days) }\end{array}$ & $\begin{array}{l}\text { S2: Quality } \\
\text { S2: Quality }\end{array}$ \\
\hline Technology & $\begin{array}{l}\text { Interoperability/Integrity (\# of exceptions, relative } \\
\text { changes) } \\
\text { Mean time between failure (of hardware elements) }\end{array}$ & $\begin{array}{l}\text { T3: Interoperability } \\
\text { T4: Accessibility and Up- } \\
\text { time }\end{array}$ \\
\hline Organization & $\begin{array}{l}\text { Capacity utilization rate internal processes }(>\mathrm{xx} \% \text {, } \\
\text { relative change) }\end{array}$ & $\mathrm{O} 2$ : Access to resources \\
\hline Finance & $\begin{array}{l}\text { Profit (xx \%, consumer segments: } 1,3,4) \\
\text { Turnover (absolute M€, consumer segment: 2) } \\
\text { Net cash flow } \\
\text { Fees from add-on services to the cost }(>X €) \\
\text { OPEX (personnel costs) } \\
\text { Marketing costs }(€)\end{array}$ & $\begin{array}{l}\text { F2: Profitability } \\
\text { F2: Profitability } \\
\text { F2: Profitability } \\
\text { F2: Profitability } \\
\text { F3: Costs } \\
\text { F3: Costs }\end{array}$ \\
\hline $\begin{array}{l}\text { Value } \\
\text { exchange }\end{array}$ & Right-sizing & $\begin{array}{l}\text { V3: Value attributed to } \\
\text { transactions }\end{array}$ \\
\hline $\begin{array}{c}\text { Information } \\
\text { exchange }\end{array}$ & $\begin{array}{l}\text { Transactions (absolute figures, relative changes) } \\
\text { Active consumer base (user categories/priority schemes } \\
\text { within segments) }\end{array}$ & $\begin{array}{l}\text { I3: Information } \\
\text { accessibility }\end{array}$ \\
\hline $\begin{array}{l}\text { Process } \\
\text { alignment }\end{array}$ & $\begin{array}{l}\text { Throughput ( } \% \text { of full capacity) } \\
\text { Utilization rate intra-organizational processes }(>\mathrm{xx} \%)\end{array}$ & $\begin{array}{l}\text { P2: Process throughput } \\
\text { P2: Process throughput }\end{array}$ \\
\hline
\end{tabular}

on what is essential. The metrics were designed to serve as guidelines for the following implementation stage, e.g., detailed architecture, detailed process modeling and road-mapping for platform change.

\subsection{Case 2: manufacturer and retailer of furniture}

The second case involves a manufacturer and retailer of furniture for households and public spaces. It is a $€ 150$ million company operating in half a dozen countries with about 1000 employees. The company was making a major change in their business by introducing e-Business solutions and applications as an alternative channel to the physical distribution outlets. 
Table 4 Design and research approach: Case 2

\begin{tabular}{|c|c|c|c|}
\hline Phasing & Task & $\begin{array}{l}\text { Concepts used } \\
\text { from kernel } \\
\text { theories }\end{array}$ & Data collection, research \\
\hline Idea & Idea formulation & & $\begin{array}{l}11 \text { Brainstorming and } \\
\text { consultancy meetings by project } \\
\text { management group of CEO, } \\
\text { CFO, CMO, CIO, Project } \\
\text { management, e-Commerce site } \\
\text { manager, developers, } \\
\text { consultants, vendors and COO } \\
\text { upon request }\end{array}$ \\
\hline $\begin{array}{l}\text { Requirement } \\
\text { elicitation }\end{array}$ & $\begin{array}{l}\text { Suggesting and selecting the } \\
\text { Business Model tooling }\end{array}$ & CSOFT & $\begin{array}{l}\text { (1) Collecting data on customers } \\
\text { (2) Selecting customer segments }\end{array}$ \\
\hline $\begin{array}{l}\text { Identification } \\
\text { of the } \\
\text { solution }\end{array}$ & $\begin{array}{l}\mathrm{BM} \text { and } \mathrm{BM} \text { metrics } \\
\text { identification }\end{array}$ & & $\begin{array}{l}\text { (3) Defining metrics } \\
\text { (4) analyzing the to-be business } \\
\text { architecture }\end{array}$ \\
\hline Prototype & $\begin{array}{l}\text { Iterative implementation of the } \\
\text { web store }\end{array}$ & SCRUM & $\begin{array}{l}\text { Alpha and beta testing of the } \\
\text { functionality }\end{array}$ \\
\hline Implementation & $\begin{array}{l}\text { Web store for one customer } \\
\text { segment was opened }\end{array}$ & $\begin{array}{l}\text { Roadmap, } \\
\text { enterprise } \\
\text { architecture } \\
\text { (EA) }\end{array}$ & $\begin{array}{l}\text { Roadmap for launching service } \\
\text { over the internet and adoption } \\
\text { of supporting software tools; } \\
\text { Metrics were utilized in keeping } \\
\text { the focus on the features in the } \\
\text { implementation phase }\end{array}$ \\
\hline Evaluation & $\begin{array}{l}\text { Monthly follow-up of the } \\
\text { metrics and decision over the } \\
\text { focus of further development } \\
\text { by the project management } \\
\text { group }\end{array}$ & & Analysis of measures \\
\hline
\end{tabular}

In this case study the same approach was followed as in Case 1, i.e., brainstorm sessions with a steering committee consisting of board representatives based on the CSOFT approach (Table 4).

CSOFT was used for business modeling. First, critical customer segments were defined. The consumer segmentation was in need of revision, but also the B2B segment provided opportunities for increasing market share with more timely service via the Internet. Because of the scarcity of resources, the board decided to prioritize the $\mathrm{B} 2 \mathrm{C}$ improvements. With the help of the Internet and an e-Commerce site, the company strived to improve the customer experience by helping customers design a suitable 'personalized' solution, starting from an enhanced product portfolio. Product and customer databases (enhanced with web functionalities), professional design help, punctual deliveries and financing were expected to be combined into a lucrative Internet-based service, with easy-to-use software tools enabling collaboration between customers and company representatives. To attain these objectives, the metrics for the private consumer segment were defined as: 
Table 5 Metrics used in Case 2

\begin{tabular}{|c|c|c|}
\hline Perspectives & Metrics & $\begin{array}{l}\text { Theme (from } \\
\text { Table 1) }\end{array}$ \\
\hline $\begin{array}{l}\text { Customer } \\
\text { value }\end{array}$ & $\begin{array}{l}\text { Coverage of the customer segment } 12-50 \% \\
\text { Unique visitors } \mathrm{x} \text { million/a, conversion rate } \mathrm{x}\end{array}$ & $\begin{array}{l}\text { C2: Market segment } \\
\text { and market share } \\
\text { C3: Website-related } \\
\text { indicators } \\
\text { C3: Website-related } \\
\text { indicators }\end{array}$ \\
\hline Service & Delivery time $1 / 3$ of industry average & S2: Quality \\
\hline Technology & $\begin{array}{l}\text { Revision of PDM and CRM systems for e-Commerce back-office } \\
\text { integration } 24 / 7 \text { availability of the selection }\end{array}$ & $\begin{array}{l}\text { T3: Interoperability } \\
\text { T4: Up-time }\end{array}$ \\
\hline Organization & Improved brand image compared to competitors & O4: Characteristics \\
\hline Finance & $\begin{array}{l}\text { Turnover increase } € x x \text { million/year } \\
\text { Minimum profit margin } \mathrm{xx} \%\end{array}$ & $\begin{array}{l}\text { F2: Profitability } \\
\text { F2: Profitability }\end{array}$ \\
\hline $\begin{array}{l}\text { Value } \\
\text { exchange }\end{array}$ & N/A & \\
\hline $\begin{array}{l}\text { Information } \\
\text { exchange }\end{array}$ & $\begin{array}{l}\text { Suppliers must provide accurate, timely, high quality information } \\
\text { in a compatible digital format to the PDM }\end{array}$ & $\begin{array}{l}\text { I2: Data exchange } \\
\text { I3: Accessibility }\end{array}$ \\
\hline $\begin{array}{l}\text { Process } \\
\text { alignment }\end{array}$ & System and e-Commerce site & P3: Process variety \\
\hline
\end{tabular}

- making the brand image better known in the segment (no specific target, industry comparison)

- delivery time $1 / 3$ of the industry average

- increase in turnover of €xx million/year

- minimum profit margin of $\mathrm{xx} \%$

There appeared to be a substantial need for the outsourcing and bundling of services beyond existing levels. To meet the targets, a much closer integration would be needed, as well as a better presentation of product data (PDM). Customer relationship systems (CRM) would have to be developed, offering a functionality that went beyond existing point-of-sales systems. In addition, a major revamp of marketing was required, building on AdWords and Facebook, and linked to the electronic magazines. The metrics (see Table 5) necessary for meeting the targets were:

- 24/7 availability of product data in an interoperable format for Product Data Management (PDM) and e-Commerce site

- coverage of the customer segment from 12 to $50 \%$

- unique visitors $\mathrm{x} \mathrm{M} / \mathrm{a}$, at a conversion rate of $\mathrm{x} \%$ (to achieve the desired increase in turnover)

Simultaneously, branding (goods, parcels, documentation, personnel outfits, outlet layout, delivery trucks and websites) had to be improved. 
A year later, the metrics were in place, but performance levels still had to be met, even though substantial progress was made in upgrading CRM systems and, to a lesser extent, improving product data quality. However, some metric goals were almost realized: Coverage had been improved substantially and the number of unique visitors was on a steady rise, but, even though a limited selection was readily available, that did not translate into an increased commercial performance.

\subsection{Case 3: Online Advertising Company}

The third case involves an online advertising company, operating as an intermediary, linking online media (e.g., websites) with available advertising spaces (e.g., banner slots) to online advertisers looking for space to place their ads (banners). Through cutting edge online systems, the core provider is able to execute, manage and optimize the so-called Real Time Bidding (RTB) process, which means that any available space on a website can be sold at a virtual auction. The RTB process is enabled by ad exchanges that accept bids for each banner spot, determine a winner (based on customizable criteria) and place the winning banner then and there. To communicate with various ad exchanges, which organize various auctions, the core provider has developed online systems that advertisers can use to take part in the bidding. System development is partly carried out by the in-house development unit, and partly outsourced to external IT suppliers.

The core provider started a few years ago as a spin-off of a larger online advertising company. Since then, it has been growing at a rapid pace, which in turn has led to an increasingly complex network of stakeholders, including websites, advertising space providers, advertisers, partners and suppliers. As a consequence, the evaluation of company performance with regard to the predefined higher-level business goals has become an increasingly complicated task.

In this project, an almost-complete design cycle was followed (see Table 6). The project was discussed during several brainstorming sessions, to identify and articulate the business need (or problem), i.e., a lack of insight into the alignment of the company's operational performance with the higher-level business goals. The project team, which consisted of the CEO, a VP, a project manager and two developers, formulated a plan to develop a DSS. The DSS enables the analysis of the alignment with the BM and operational business processes and activities within the company, as well as its surrounding networked stakeholders.

First, the company's BM was formulated using the CANVAS framework. The $\mathrm{BM}$ was used to recapitulate the core value propositions, core services, first-tier partners and high-level business activities. The team extended the BM description by including the core business processes inside and outside the company. With regard to the networked partners, a description of the value creation and provisioning activities, information and knowledge creation and sharing, and lower-level business processes between stakeholders was included.

By conducting a broad literature study on the available metrics and carrying out several semi-structured interviews with various staff members, a large set of relevant candidate metrics were extracted, which were reviewed iteratively by the same interviewees. A final set of metrics, including performance levels, was 
Table 6 Design and research approach: Case 3

\begin{tabular}{|c|c|c|c|}
\hline Phasing & Task & $\begin{array}{l}\text { Concepts used } \\
\text { from kernel } \\
\text { theories }\end{array}$ & Data collection, research \\
\hline Idea & $\begin{array}{l}\text { Brainstorming about the } \\
\text { company's business need, } \\
\text { initial conception of a } \\
\text { possible solution, and } \\
\text { alternative solutions: The } \\
\text { company aims at analyzing } \\
\text { the alignment between the } \\
\text { company business model } \\
\text { with the operational business } \\
\text { processes that cut across the } \\
\text { company and its surrounding } \\
\text { business network }\end{array}$ & $\begin{array}{l}\text { Management } \\
\text { Information } \\
\text { Systems: } \\
\text { decision support } \\
\text { systems }\end{array}$ & $\begin{array}{l}\text { Four meetings with company's } \\
\text { CEO, VP, project manager } \\
\text { and two developers }\end{array}$ \\
\hline $\begin{array}{l}\text { Requirement } \\
\text { elicitation }\end{array}$ & $\begin{array}{l}\text { Suggesting and selecting the } \\
\text { Business } \\
\text { Model tooling that makes it } \\
\text { possible to represent the } \\
\text { business goals, business } \\
\text { logic and surrounding } \\
\text { business network Concepts } \\
\text { have to be formulated on a } \\
\text { level of detail matching } \\
\text { business requirements: } \\
\text { CANVAS is chosen to } \\
\text { represent how the current } \\
\text { business is structured }\end{array}$ & $\begin{array}{l}\text { CANVAS } \\
\text { Process modeling }\end{array}$ & $\begin{array}{l}\text { Collecting data from the } \\
\text { existing data repositories }\end{array}$ \\
\hline $\begin{array}{l}\text { Identification } \\
\text { of the } \\
\text { solution }\end{array}$ & Metrics identification & $\begin{array}{l}\text { Business and } \\
\text { operative metrics } \\
\text { matched with } \\
\text { BM and } \\
\text { operations }\end{array}$ & $\begin{array}{l}\text { Defining metrics: } \\
\text { Alignment of the business } \\
\text { model with the creation and } \\
\text { exchange of value and } \\
\text { information as well as } \\
\text { business processes within } \\
\text { and among the actors } \\
\text { involved }\end{array}$ \\
\hline Prototype & $\begin{array}{l}\text { Alpha-version dashboard } \\
\text { development }\end{array}$ & & Dummy data \\
\hline Implementation & Dashboard & & $\begin{array}{l}\text { Real-time data from company } \\
\text { information systems }\end{array}$ \\
\hline Evaluation & $\begin{array}{l}\text { Validation of system (i.e., } \\
\text { dashboard) output, and } \\
\text { system effectiveness or } \\
\text { meaningfulness }\end{array}$ & & $\begin{array}{l}\text { By changing the data input, the } \\
\text { dashboard calculation and } \\
\text { visualization reliability is } \\
\text { tested } \\
\text { Through semi-structured } \\
\text { interviews with the CEO and } \\
\text { VP, the output } \\
\text { meaningfulness, and hence } \\
\text { system effectiveness, is } \\
\text { evaluated }\end{array}$ \\
\hline
\end{tabular}


selected (see Table 7). The main selection criteria were: including metrics that help analyze the creation and exchange of value and information and business processes within and between stakeholders (including customers). Once the metrics had been determined, the development of a dashboard prototype was started. During this phase, the developers sketched the design of the DSS system, including the user interface, input data (access to the data repository and company information systems that would be needed) and output visualization. At this stage, dummy data was used to evaluate the prototype. Subsequently, in a small-scale implementation, the dashboard was connected to one of the company's information systems. In this process, based on real data, several graphs making use of the dashboard could be generated.

The reliability, correctness and actuality of the DSS system was verified by manipulating the input data and controlling the data output. In addition, the actual effectiveness of the output for business was evaluated qualitatively. In this regard, the CEO and the VP, who would be the main users of this product, were interviewed about the meaningfulness of the system output. The interviewees reported a strong positive experience. The system enables them to analyze the company's operational performance in a quantitative way, in particular the dynamic interaction between the company and its networked partners.

In the next phase, the company will expand the DSS system by connecting it to more information systems within the company. In addition, it will use longitudinal data (i.e., archiving the dashboard data) to analyze the company BM viability over time, helping the company assess its current (BM) implementation progress, which in turn helps it adjust its BM.

\subsection{Case 4: environment protection agencies}

This case involves the Regionale Uitvoeringsdiensten in the Netherlands. RUDs are agencies responsible for the execution of government tasks at the regional level. New legislation has come into place that transfers all activities with regard to granting permits in relation to the environmental impact of industries, as well as the monitoring and enforcements of this legislation, from municipalities to Regionale Uitvoeringsdiensten (Regional Execution Services).

These RUDs were formed as a response to major incidents in the Netherlands, such as the explosion of a fireworks factory in Enschede and a large fire in the Port of Rotterdam. Centralizing the granting of permits and their enforcement should increase the knowledge and resilience of the agencies compared to the previous situation, in which small municipalities are used to be responsible without sufficient resources and expertise.

In all, 28 RUDs were established. The RUDs were formed in a bottom-up iterative process, guided by quality metrics set at a national level. It appears that this allows RUDs to comply with the national criteria with different approaches and business designs. We were actively involved in the design of one of the RUDs in the Province of South Holland, to which this case relates. The generic design process involved a number of steps. We studied the outcomes of the process through analyses of, and policy documents and BMs based on CANVAS with public instead 
Table 7 Metrics used in Case 3

\begin{tabular}{|c|c|c|}
\hline Perspectives & Metrics & Theme (from Table 1) \\
\hline $\begin{array}{l}\text { Customer } \\
\text { Value }\end{array}$ & Average number of repeated buys per customers & $\begin{array}{l}\text { C2: Market segment } \\
\text { and market share }\end{array}$ \\
\hline Service & $\begin{array}{l}\text { Customers' retention percentage } \\
\text { Development time new service development } \\
\text { Number of customer complaints }\end{array}$ & $\begin{array}{l}\text { S4: Sustainability } \\
\text { S1: Development time } \\
\text { S3: Satisfaction }\end{array}$ \\
\hline Technology & $\begin{array}{l}\text { Interoperability/integrity (\# of exceptions, relative changes) } \\
\text { Mean Time Between Failure (of hardware elements) }\end{array}$ & $\begin{array}{l}\text { T3: Interoperability } \\
\text { T4: Accessibility and } \\
\text { Up-time }\end{array}$ \\
\hline Organization & $\begin{array}{l}\text { Proportion RandD employees, proportion cross-unit } \\
\text { collaborations }\end{array}$ & $\begin{array}{l}\text { O1: Number of } \\
\text { internal partners }\end{array}$ \\
\hline Finance & $\begin{array}{l}\text { Net cash flow, EBIT (Earnings Before Interest Tax), } \\
\text { Schedule Adherence (Proportion of projects on time), } \\
\text { Proportion RandD expenditures and earnings }\end{array}$ & $\begin{array}{l}\text { F2: Profitability } \\
\text { F3: Costs }\end{array}$ \\
\hline $\begin{array}{l}\text { Networked } \\
\text { value } \\
\text { exchange }\end{array}$ & $\begin{array}{l}\text { Frequency of repeated partners' transactions, Shared } \\
\text { customers' profiles, Number of contracts per partner, } \\
\text { Number of collaborative innovative projects, Percentage } \\
\text { shared intended values (versus achieved) }\end{array}$ & $\begin{array}{l}\text { V3: Value attributed } \\
\text { to transactions } \\
\text { V2: Value exchange } \\
\text { between partners } \\
\text { V1: Number of } \\
\text { partners } \\
\text { V4: Value conflicts }\end{array}$ \\
\hline $\begin{array}{l}\text { Information } \\
\text { exchange }\end{array}$ & $\begin{array}{l}\text { Average support hours spent per employee (both insiders and } \\
\text { partners), Proportion of data and information exchange, } \\
\text { Number of access points to external information systems, } \\
\text { Number of share information systems, Number of } \\
\text { dedicated contact persons on partner's side }\end{array}$ & $\begin{array}{l}\text { I4: Knowledge } \\
\text { development } \\
\text { I2: Data exchange } \\
\text { I3: Information } \\
\text { accessibility } \\
\text { I3: Information } \\
\text { accessibility } \\
\text { I1: Number of } \\
\text { partners involved }\end{array}$ \\
\hline $\begin{array}{l}\text { Process } \\
\text { alignment }\end{array}$ & $\begin{array}{l}\text { Number of bugs/complaints reported by partners (in shared } \\
\text { systems), Average time debugging shared systems, Bug } \\
\text { closure rate, Number of partners' requests for missing } \\
\text { features, (Share) solution interoperability percentage, } \\
\text { Average system migration time for shared systems, } \\
\text { Percentage of service agility }\end{array}$ & $\begin{array}{l}\text { P2: Process } \\
\text { throughput } \\
\text { P2: Process } \\
\text { throughput } \\
\text { P2: Process } \\
\text { throughput } \\
\text { P2: Process } \\
\text { throughput } \\
\text { P2: Process } \\
\text { throughput } \\
\text { P3: Process variety }\end{array}$ \\
\hline
\end{tabular}

of economic values as a core element. As researchers, we were closely involved in the translation of the BM toward EA and process descriptions that were used to configure IT applications and train employees (Table 8). 
Table 8 Design and research approach: Case 4

\begin{tabular}{|c|c|c|c|}
\hline Phasing & Task & $\begin{array}{l}\text { Concepts } \\
\text { used from } \\
\text { kernel } \\
\text { theories }\end{array}$ & Data collection, research \\
\hline Idea & $\begin{array}{l}\text { RUD concept development, } \\
\text { policy-making and negotiations } \\
\text { between central government and } \\
\text { Association of Dutch } \\
\text { Municipalities }\end{array}$ & $\begin{array}{l}\text { Quality } \\
\text { models }\end{array}$ & $\begin{array}{l}\text { Outcomes of this phase were } \\
\text { presented through notes and } \\
\text { memorandums of understanding } \\
\text { (Mans 2008; VNG 2009) }\end{array}$ \\
\hline $\begin{array}{l}\text { Requirement } \\
\text { elicitation }\end{array}$ & $\begin{array}{l}\text { Bottom-up linkages. } \\
\text { Municipalities and provinces in } \\
\text { the Netherlands formed } \\
\text { coalitions to start an RUD }\end{array}$ & N/A & $\begin{array}{l}\text { Led to } 28 \text { RUDs in three different } \\
\text { models; of these, } 7 \text { were studied } \\
\text { in more detail on the basis of } \\
\text { their business plans }\end{array}$ \\
\hline $\begin{array}{l}\text { Identification } \\
\text { of the } \\
\text { solution }\end{array}$ & $\begin{array}{l}\text { Elicitation of business model and } \\
\text { business design }\end{array}$ & $\begin{array}{l}\text { Business } \\
\text { Model } \\
\text { CANVAS } \\
\text { ArchiMate }\end{array}$ & Defining metrics \\
\hline Prototype & N/A & & \\
\hline Implementation & $\begin{array}{l}\text { From business model to process } \\
\text { model, Translating existing } \\
\text { standards to specific setting of } \\
\text { RUD, Implementing ICT } \\
\text { infrastructure, developing } \\
\text { training material for employees }\end{array}$ & $\begin{array}{l}\text { EA, } \\
\text { ArchiMate }\end{array}$ & $\begin{array}{l}\text { Goal analysis } \\
\text { Architecture patterns } \\
\text { Process management and } \\
\text { optimization EA modeling/ } \\
\text { process analysis }\end{array}$ \\
\hline Evaluation & N/A & N/A & N/A \\
\hline
\end{tabular}

In the first step, a number of metrics were developed (Table 9). They involve satisfaction with the services, service quality, safety and cost. These indicators have been the subject of long-lasting political discussions and did not yet impose any major restrictions on the business design. The municipalities continued to be responsible, but they delegated the tasks to their RUD.

In the next steps, the municipalities formed coalitions among each other and together with provinces. Every coalition developed a business plan, including a high-level design of the RUDs. Three designs were proposed: (1) a centralized design, with a central organization and centralized IT; (2) a decentralized design, with a central organization and re-use of existing processes and services of the municipalities involved; and (3) a virtual organization with the partners working closely together. Of the 28 RUDs, three chose the virtual organization, while the rest selected one of the two other designs. The RUD in our study adopted the centralized model, which required the collaboration of a number of municipalities and the province. Needless to say, the outcome is very different with respect to the network constellation and IT solutions, even though they all are to comply with the predetermined output and input criteria.

Only a few of the 28 RUDs at this point are fully operational (including the one in our case study). It will be interesting to see how compliance to the performance criteria will evolve over time and whether the different network designs lead to different performance levels. 
Table 9 Metrics used in Case 4

\begin{tabular}{|c|c|c|}
\hline Perspectives & Metrics & Theme (from Table 1) \\
\hline Customer Value & Societal (non-tangible) values: safety and security & $\mathrm{C} 1$ : Created customer value \\
\hline \multirow[t]{5}{*}{ Service } & Level of compliance (\# of non-compliance cases) & S2: Quality \\
\hline & Quality of enforcement & S2: Quality \\
\hline & Constant user experience, availability, reliability & S3: Satisfaction \\
\hline & Customer satisfaction & S3: Satisfaction \\
\hline & Transparency of tasks and performance & S2: Quality \\
\hline \multirow[t]{2}{*}{ Technology } & Information quality—single customer/location file & T2: Data complexity \\
\hline & $\begin{array}{l}\text { Up-time/response time should increase to } 24 / 7 \text {, } \\
\text { especially for incidents }\end{array}$ & $\begin{array}{l}\text { T4: Accessibility and Up- } \\
\text { time }\end{array}$ \\
\hline \multirow[t]{2}{*}{ Organization } & More skilled employees; specialization & O2: Access to resources \\
\hline & $\begin{array}{l}\text { Fewer contract (hired) people, more internal } \\
\text { knowledge }\end{array}$ & $\begin{array}{l}\text { O3: Number of external } \\
\text { partners }\end{array}$ \\
\hline \multirow[t]{3}{*}{ Finance } & Better quality at lower operational cost, specified & F2: Profitability \\
\hline & develonment cost & F3: Costs \\
\hline & Pre-financed by participant & F4: Risks \\
\hline Value exchange & Resilience at lower costs & $\begin{array}{l}\text { V2: Value exchange } \\
\text { between partners }\end{array}$ \\
\hline \multirow{3}{*}{$\begin{array}{c}\text { Information } \\
\text { exchange }\end{array}$} & Number of partners involved in information exchange & I1: Number of partners \\
\hline & Ubiquitous access for employees to services & I3: Information accessibility \\
\hline & Flexibility of working environment & \\
\hline \multirow{4}{*}{$\begin{array}{l}\text { Process } \\
\text { alignment }\end{array}$} & Simplified processes & P3: Process variety \\
\hline & Number of redundant processes & P1: Number of processes \\
\hline & Stable performance (due to the larger scale) & P2: Process throughput \\
\hline & Level of process standardization & P3: Process variety \\
\hline
\end{tabular}

\section{Findings and reflection}

The four cases are very heterogeneous in nature. Cases 1 and 2 involve individual organizations with an attempt to revise their BM with an outlook on their external network of suppliers, whereas the design of the business network is the key effort in the other two cases.

In the first case, in addition to financial BM metrics, measuring the market segment and market share was essential, as well as more specific metrics for service quality and process throughput. In the second case, the revised BM required a lot of changes in the existing back-office systems to support the new operating model and thus the financial metrics are accompanied with several website and information systems interoperability-related metrics. In the last two cases the metrics are more elaborate in mapping the interdependencies with partner organizations. Although Case 3 is more focused on process alignment and Case 4 is a design case toward predetermined operational performance measures, the design of business value through information exchange and process alignment within the organizational network is vital in both. Case 4 is a typical public sector case in its intangible nature 
values that are hard to monetize, i.e., increasing the safety and security of citizens from environmental hazards.

Our BM metrics repository was structured into eight perspectives. Interestingly, in three out of four cases, the set of metrics covered all eight perspectives-only Case 2 decided to cover seven perspectives and not to have metrics for value exchange. The number of metrics adopted in each case varied from 12 to 24 . Customer value was typically measured with Market segment or share (C2), Service with quality metrics (S2), Technology with accessibility and up-time (T4), Finance with profitability (F2), Information exchange between partners with information accessibility metrics (I3) and Process alignment with process throughput-related metrics (P2). Strikingly, metrics on organizational perspective (O) and value exchange between partners (V) were neither coherent nor focused in our cases.

The three perspectives of the repository on business network-related metrics (V, I and $\mathrm{P}$ ) were most explicit in the online advertisement case. When examining more carefully the types of network-related metrics defined in the cases, it seems that the other companies are used to dominating their subcontractors instead of focusing on gaining access to information for interorganizational process throughput.

We can see from the cases that measuring the financial profitability (F2) and technological accessibility (T4) were considered especially important-they were included in all four cases. The next most adopted metrics were related to service quality (S2), costs (F3), technical interoperability (T3), information accessibility (I3) and process throughput (P2).

However, if we look on a detailed level into the specific metrics proposed in the cases, it is hard to find a consistent pattern. This illustrates that every case is unique. For instance, although service quality (S2) and satisfaction metrics (S3) were relevant to most e-Business cases, specifically the e-Government case employed the broadest set of metrics under these themes. It is understandable, as public service is designed for a wide range of stakeholders.

Drawing upon the above findings, we suggest that when companies are designing their e-BMs and related metrics, it could be worthwhile to consider measuring the perspectives and topics suggested in our repository (Table 1). The specific metrics listed in the repository in turn function best as examples of metrics applied in previous settings and can be modified or replaced with metrics unique to the situation at hand.

In addition, an important finding from the cases is that the metrics were discussed and decided already before prototyping and/or implementing the BM designs. The design cases illustrate that defining clear, adapted metrics is actually a central means for the management to maintain strategic focus throughout the design and implementation of the new business logic.

Moreover, the set of measures served as the baseline to evaluate the effectiveness of the change at the operational level and to decide over further development efforts. In Cases 1 and 2, roadmaps were designed for reaching the specified target levels determined for the metrics.

As a scientific contribution, we continue the discussion on the role of business modeling as a tool for addressing and analyzing innovation and business (re)design (Demil and Lecocq 2010). This is in line with the discourse in BM literature 
(Baden-Fuller et al. 2010; Robins 2013), which has brought into focus the view that Business Modeling should be seen as a learning (Itami and Nishino 2010) and planning process where BM assumptions are both articulated and tested (McGrath 2010). We suggest that by defining metrics for BM, this testing and learning process can become more rigorous. Our proposal to have both financial and non-financial metrics for several BM components resonates, for example, with findings by Dossi and Patelli (2010) on how inclusion of non-financial metrics supported learning and dialogue in relationships between partners. It also matches with the conclusions of Melnyk et al. (2010) that organizations aiming at innovation and business renewal must change their selection of performance metrics to focus less on the intended outcomes and more on the means by which these outcomes are to be achieved. Our view, supported by the findings from the empirical design cases, is that the BM describes just those means and thus provides a solid structure for constructing a balanced set of metrics.

Finally, in line with Ittner and Larcker (2003), we list four considerations of metrics in designing BM. The first is the relationship between strategy and measures. Keeping in mind that BMs are meant to achieve strategic objectives (Cortimiglia et al. 2015), we propose linking and customizing metrics to the relevant elements of the BM and maintaining the alignment throughout the design. A second important consideration is to identify and follow up with those metrics, from which it can be assumed that there are plausible causalities between strategy, BM and implementation, i.e., how planned changes actuate outcomes, and how inputs and outputs of actions are related. Developing BMs simultaneously with metrics helps managers to understand inherent dynamics, while at the same time providing insight into positive or negative externalities of the actions in the complex, networked environment. In other words, using metrics is a prerequisite for targeted corrective actions and business agility in implementing BMs. Thirdly, finding right values for performance metrics with proper definition of objectives in the context is essential. Striving for $100 \%$ customer satisfaction or $80 \%$ market share is not realistic. Metrics provide a useful means to discuss and reframe relevant strategic business objectives and operational implementations of business logic as represented by a BM. Lastly, it is not only about correct measures, but also about measuring correctly, i.e., ensuring relevant, reliable and valid data for metrics-not merely using what is present at hand. In the above design cases we noticed that it was necessary not only to decide on the metrics, but to implement them meticulously with enhanced information systems.

The following suggestion was given at the outset of the cases: "If managers or $\mathrm{BM}$ designers want to (re)design a BM that is viable and feasible, then use of a set of metrics will help to focus the BM on the desired strategic outcomes and define relevant performance levels for operational implementations." This proposition can be supported based on the four cases. We can conclude that metrics are of value in directing BM analysis by helping to identify core hindrances and opportunities in existing, or new BMs. They are also of help in understanding — and creating a shared understanding of - causality and dynamics with regard to the effects of the actions. This in turn is useful in finding corrective actions during the implementation of the BMs 
In addition, the design cases show how a stronger focus on metrics and performance levels during BM design leads to more well-articulated objectives, which help to maintain alignment and integrity of strategy while implementing BMs in practice. It was also deemed important that the design process included discussions among the vested stakeholders about realistic target levels of metrics in relation to (inter)organizational business processes, and especially in relationship with ICT, EA, or software development practice (Di Valentin et al. 2012).

\section{Conclusion}

Literature on BM and BM innovation, specifically from a design perspective, has for a long time lacked a focus on metrics (Busi and Bititci 2006). Although metrics are defined and used in BM design practices, there is no systematic grounding in PM literature, and generally speaking, metrics and performance levels in BM research are limited to financial aspects (Bouwman and Van den Ham 2003; Heikkilä et al. 2014). This paper contributes to the previous literature by synthesizing a BM metrics repository. The proposed structure encompasses eight BM perspectives that are commonly discussed in the literature: Customer value, Services, Technology, Organizations, Finances, Value exchange, Information exchange and Process alignment. We illustrate its applicability through the extensive discussion of four e-Business model design cases. We use the repository to illustrate the use of metrics in BM (re)design within organizations and business networks. The major contribution of this paper is that we were able to compile a repository of metrics, but also show how the metrics were adjusted, modified and applied in the design of BMs in real-life design cases with quite different characteristics.

Even though the reported e-Business cases were diverse, the metrics set by the steering boards of design cases converged already in the set noted in this paper: Three cases covered all eight perspectives of the BM metrics repository and one case included seven perspectives. Especially Financial profitability (F2) and Technological accessibility (T4) were considered vital and were included in all cases. The next most adopted topics were related to service quality (S2), costs (F3), technical interoperability (T3), information accessibility (I3) and process throughput (P2). Despite the fact that financial metrics dominated during the design, the sphere of performance measurement expanded toward more qualitative metrics of value (reflecting the social context and expanding the BM realm) and on the other hand toward hard technological performance metrics (reflecting the driving force of technology in e-Business).

On a practical level we suggest that managers working with BM designs make issues at stake measurable by utilizing the perspectives and topics suggested in this article (Table 1). The repository of specific metrics serves as a source of examples that can be modified or replaced with metrics tailored to the BM being designed. We also suggest that the metrics are discussed and already set before the prototyping and/or implementation phase of the e-Business. This should lead to less value-laden brainstorming and increased practical focus in (re)designing BMs. The empirical cases show how metrics were utilized in maintaining strategic focus throughout the 
design and implementation, in evaluating the effectiveness of the change and in deciding over further development efforts.

In addition to organizations and networks (re)designing their BMs, also the BM tool vendors could benefit from a repository of relevant metrics, especially if they can accumulate the body of knowledge on metrics in various contexts. Furthermore, the repository can help business analysts to estimate adequate performance levels for ecosystems.

This paper has a number of limitations that should be taken into account. First of all, there is primarily a conceptual and design character to the paper and it needs to be evaluated and confirmed in future empirical case studies and surveys. We chose design cases to provide insight into the use of metrics, but the findings need to be backed up with more cases, preferably with a focus on ecosystem design with varying success. Furthermore, the structure of BM metrics repository is derived from BM ontology elements. However, this structure may not fit with all the BM frameworks and approaches available. Therefore, instead of the one-for-all structure approach taken in this paper, the repository could, in future, have more agile structure and provide different lists of metrics for differing BM frameworks.

More metrics and indicators can undoubtedly be found in literature, but not all metrics will make sense in some BM design. It is not about more, but about more focused, relevant metrics for business modeling and implementation. The availability of large data sets (big data) entails the risk that everything that is measured is relevant, while we would argue that BM thinking with metrics could help managers to focus on the essential and to maintain strategic integrity.

It would be interesting to further investigate the process of BM design and how the repository of metrics could be incorporated into it. Moreover, an interesting discussion concerns the dynamics of metrics. The dilemma is that committing to a fixed set of metrics contributes to the rigorous BM design process, but at the same time reduces flexibility to make changes to the BM. Johnson (2010) point out that metrics often are evolving during the development of the BM. Our initial understanding is that the metrics will and should change and adapt to the evolution. To investigate this topic, we need more confirmatory evidence on the change of metrics during and after the BMD before we can make claims on the dynamics of metrics.

Moreover, we want to stress that using the repository is heuristic, providing an open repository with tentative measures. They have to be examined and clearly understood in context anyway. In the future, we expect the agility, flexibility and resilience of networked businesses or ecosystems to become more and more important. Consequently, understanding the dynamics of Business Modeling and the adaptation of flexible metrics in networked environments is highly relevant and requires the growing attention of researchers. Therefore, we call for further theoretical validation and elaboration and (empirical) evaluation and application of the metrics in different contexts. In practice we see a clear demand from companies to translate their BM and business logic into a small flexible set of sustainable metrics that help to focus and to monitor. 


\section{References}

Afuah A, Tucci C (2003) Internet business models and strategies. McGraw-Hill, New York

Alarcón LF, Ashley DB (1996) Modeling project performance for decision making. J Constr Eng Manag 112:265-273

Al-Debei MM, Avison D (2010) Developing a unified framework of the BM concept. Eur J Inf Syst 19:359-376

Baden-Fuller C, Haefliger S (2013) Business models and technological innovation. Long Range Plan 46:419-426

Baden-Fuller C, Demil B, Lecoq X, MacMillan I (2010) Editorial. Long Range Plan 43:143-145

Bose R (2004) Knowledge management metrics. Ind Manag Data Syst 104:457-468

Bouwman H (2003) Designing metrics for business models describing mobile services delivered by networked organizations. In: Proceedings of the 16th bled electronic commerce conference eTransformation. Bled, Slovenia

Bouwman H, van den Ham E (2003) Business models and eMetrics, a state of the art. In: Preissl B, Bouwman H, Steinfield C (eds) E-Life after the Dot.com bust. Physica Verlag, Berlin, pp 83-100

Bouwman H, de Vos H, Haaker T (2008) Mobile service innovation and business models. Springer, Berlin

Bouwman H, De Reuver M, Solaimani S, Daas D, Haaker T, Janssen W, Iske P, Walenkamp B (2012) Business models, tooling and research agenda. In: Clark R, Pucihar A, Gricar J (eds) The first 25 years of the bled conference. Kraj, Moderna organizacija

Busi M, Bititci US (2006) Collaborative performance management: present gaps and future research. Int J Product Perform Manag 55:7-25

Camarinha-Matos LM, Abreu A (2007) Performance indicators for collaborative networks based on collaboration benefits. Prod Plan Control Manag Oper 18:592-609

Carr N (2006) Designerly ways of knowing. Springer, London

Casadesus-Masanell R, Ricart JE (2010) From strategy to business models and onto tactics. Long Range Plan 43:195-215

Choong KK (2014) The fundamentals of performance measurement systems: a systematic approach to theory and a research agenda. Int J Product Perform Manag 63:879-922

Chun T, Law R (2003) Developing a performance indicator for hotel websites. Hosp Manag 22(1):119-125

Cocca P, Alberti M (2010) A framework to assess performance measurement systems in SMEs. Int J Product Perform Manag 59:186-200

Cortimiglia M, Ghezzi A, Frank A (2015) Business model innovation and strategy making nexus: evidence from a cross-industry mixed-methods study. R\&D Manag. doi:10.1111/radm.12113

Cross KF, Lynch RL (1988) The "SMART" way to define and sustain success. Natl Product Rev 8:23-33

Daas D, Hurkmans T, Overbeek S, Bouwman H (2013) Developing a decision support system for business model design. Electron Mark 23(3):251-265

De Reuver M, Bouwman H (2012) Governing mobile service innovation in converging value networks. J Bus Res 65:347-354

De Reuver M, Bouwman H, Haaker T (2013) Business model roadmapping: a practical approach to come from an existing to a desired business model. Int J Innov Manag 17:1-18

Demil B, Lecocq X (2010) Business model evolution: in search of dynamic consistency. Long Range Plan 43:227-246

Di Valentin C, Werthe D, Loos P, Weiblen T (2012) Quantifying the quality of business models. In: Proceedings of the 5th international conference in human-oriented and personalized mechanisms, technologies and services. IARA

Dossi A, Patelli L (2010) You learn from what you measure: financial and non-financial performance measures in multinational companies. Long Range Plan 43:498-526

Dubosson-Torbay M, Osterwalder A, Pigneur Y (2002) E-Business model design, classification, and measurements. Thunderbird Int Bus Rev 44(1):5-23. doi:10.1002/tie.1036

Eckerson WW (2009) Performance management strategies: how to Create and Deploy Effective Metrics. Bus Intell J 14:24-27

Edvinsson L, Malone MS (1997) Intellectual capital: realizing your company's true value by finding its hidden brainpower. HarperBusiness, New York 
El Sawy O, Pereira F (2013) Business modelling in the dynamic digital space. Springer briefs in digital spaces Springer, p. 68

Epstein MJ, Roy MJ (2001) Sustainability in action: identifying and measuring the key performance drivers. Long Range Plan 34:585-604

Ferreira PS, Shamsuzzoha A, Toscano C, Cunha P (2012) Framework or performance measurement and management in a collaborative business environment. Int J Product Perform Manag 61:672-690

Folan P, Browne J (2005) A review of performance measurement: towards performance management. Comput Ind 56:663-680

Fritscher B, Pigneur Y (2011) Business IT alignment from Business model to enterprise architecture. The Advanced Information Systems Engineering Workshops, Heidelberg

Ghalayini AM, Noble JS, Crowe TJ (1997) An integrated dynamic performance measurement system for improving manufacturing competitiveness. Int J Prod Econ 48:207-225

Gordijn J, Akkermans H (2001) E3-value: design and evaluation of E-business models. IEEE Intell Syst 16:11-17

Gordijn J, Akkermans JM, Van Vliet JC (2000) What's in an electronic business model, 12th international conference of knowledge engineering and knowledge management. Springer, Berlin, pp 257-273

Graser F, Jansson K, Eschenbächer J, Westphal I, Negretto U (2005) Towards performance measurement in virtual organizations. In: Camarinha-Matos L, Afsarmanesh H, Ortiz A (eds) Collaborative networks and their breeding environments. Springer, Heidelberg

Gregor S (2006) The nature of theory in information systems. MIS Q 30:611-642

Gunasekaran A, Patel C, McGaughey RE (2004) A framework for supply chain performance measurement. Int J Prod Econ 87:333-347

Harbour JL (2009) The basics of performance measurement, 2nd edn. Taylor and Francis Group, New York

Hedman J, Kalling T (2003) The business model concept: theoretical underpinnings and empirical illustrations. Eur J Inf Sci 12:49-59

Heikkilä M, Heikkilä J (2010) Conscription of Network Business Models. IUP J Bus Strategy 7:7-23

Heikkilä M, Heikkilä J (2013) Collaborative business model innovation process for networked services. Co-created effective, agile, and trusted eServices. Springer Berlin, pp 133-147

Heikkilä J, Heikkilä M, Lehmonen J (2005) Sharing for understanding and doing for learning: an Emerging Learning Business Network. ICFAI J Knowl Manag 3:28-45

Heikkilä J, Tyrväinen P, Heikkilä M (2010) Designing for performance - a technique for business model estimation. In: Seppä M, Helander N, Ilvonen I (eds) Proceedings of EBRF. Research Forum to Understand Business in Knowledge Society

Heikkilä M, Solaimani S, Soudunsaari A, Hakanen M, Kuivaniemi L, Suoranta M (2014) Performance estimation of networked business models: case study on a Finnish eHealth Service Project. J Bus Models 2:71-88

Hudson M, Lean J, Smart PA (2001) Improving control through effective performance measurement in SMEs. Prod Plan Control 12:804-813

Itami H, Nishino K (2010) Killing two birds with one stone: profit for now and learning for the future. Long Range Plan 43:364-369

Ittner CD, Larcker DF (2003) Coming up short on nonfinancial performance measurement. Harvard Bus Rev 81:88-95

Janssen W, Bouwman H, van Buuren R, Haaker T (2014) An organizational competence model for innovation intermediaries. Eur J Innov Manag 17:2-24

Johnson MW (2010) Seizing the white space: business model innovation for growth and renewal. Harvard Business Press, Watertown

Johnson MW, Christensen CM, Kagermann H (2008) Reinventing your business model. Harvard Bus Rev 86:57-68

Kaplan RS (2001) Strategic performance measurement and management in nonprofit organizations. Nonprofit Manag Leadersh 11:353-370

Kaplan RS, Norton DP (1992) The balanced scorecard-measures that drive performance. Harvard Bus Rev 70:71-79

Kaplan RS, Norton DP (1993) Putting the balanced scorecard to work. Harvard Business Review September-October, pp 134-147

Kaplan RS, Norton DP (1996) Using the balanced scorecard as a strategic management system. Harvard Bus Rev 74:75-85 
Kaplan RS, Norton DP (2001) Transforming the balanced scorecard from performance measurement to strategic management: part I. Account Horiz 15:87-104

Keegan DP, Eiler RG, Jones CR (1989) Are your performance measures obsolete? Manag Account $70: 45-50$

Krippendorff K (2006) The semantic turn: a new foundation for design. Taylor and Francis, London

Kulmala HI, Lonnqvist A (2006) Performance measurement of networks: towards a non-financial approach. Int J Netw Virtual Organ 3:299-316

Lambert SC, Davidson RA (2013) Applications of the business model in studies of enterprise success, innovation and classification: an analysis of empirical research from 1996 to 2010. Eur Manag J 31:668-681

Marr B (2012) Key performance indicators: the 75 measures every manager needs to know. FT Press, London

McGrath RG (2010) Business models: a discovery driven approach. Long Range Plan 43:247-261

Medori D, Steeple D (2000) A framework for auditing and enhancing performance measurement systems. Int J Oper Prod Manag 20:520-533

Melnyk SA, Hanson JD, Calantone RJ (2010) Hitting the target... but missing the point: resolving the paradox of strategic transition. Long Range Plan 43:555-574

Miles M, Huberman M (1994) Qualitative data analysis: an expanded sourcebook. Sage, Thousand Oaks

Najmi M, Rigas J, Fan IS (2005) A framework to review performance measurement systems. Bus Process Manag J 11:109-122

Neely AD (1994) Performance measurement system design: third phase, Performance Measurement System Design Workbook, April

Neely AD (2005) The evolution of performance measurement research: developments in the last decade and a research agenda for the next. Int J Oper Prod Manag 25:1264-1277

Neely AD, Adams C (2001) The performance prism perspective. J Cost Manag 15:7-15

Neely AD, Gregory M, Platts K (1995) Performance measurement system design: a literature review and research agenda. Int J Oper Prod Manag 15:80-116

Neely AD, Mills J, Platts K, Richards H, Gregory M, Bourne M, Kennerley M (2000) Performance measurement system design: developing and testing a process-based approach. Int J Oper Prod Manag 20:1119-1145

Neely AD, Adam C, Kennerley M (2002) The performance prism. Prentice Hall, Englewood Cliffs

Osterwalder A, Pigneur Y (2002) An e-Business model ontology for modeling e-Business. In: Loebbecke et al. (eds) Proceedings of the 15th bled conference on E-commerce. Bled, Slovenia

Osterwalder A, Pigneur Y (2010) Business model generation: a handbook for visionaries, game changers, and challengers. Wiley, New York

Pfeffers K, Tuunanen T, Rothenberger MA, Chatterjee A (2007) A design science research methodology for information systems research. J Manag Inf Syst 24:45-77

Pritchard JP, Armistead C (1999) Business process management: lessons from European business. Bus Process Manag J 5:10-35

Rayport J, Jaworski B (2001) E-Commerce. McGraw-Hill/Irwin, New York, NY

Robins J (2013) Editorial. Long Range Plan 46:417-418

Rouse P, Putterill M (2003) An integral framework for performance measurement. Manag Decis 41:791-805

Salancik J, Pfeffer GR (2003) The external control of organizations: a resource dependence perspective. Stanford University Press, Redwood City

Sein MK, Henfridsson O, Purao S, Rossi M, Lindgren R (2011) Action design research. MIS Q 35:37-57

Shane B (1997) Improved performance measurement: prerequisite for better service delivery. J Public Sector Manag 27:1-5

Shane B (1998) Implementing a performance measurement system in a public service information function. Optimum 28:36-44

Sink S, Tuttle T (1989) Planning and measurement in your organization of the future. Industrial Engineering and Management Press, Norcross, GA

Smith A (2006) CRM and customer service: strategic asset or corporate overhead? Handb Bus Strategy 7:87-93

Solaimani S, Bouwman H (2012) A framework for the alignment of business model and business processes: a generic model for trans-sector innovation. Bus Process Manag J 8:655-679

Solaimani S, Guldemond N, Bouwman H (2013a) Dynamic stakeholder interaction analysis: innovative Smart Living design cases. Electron Mark 23:317-328 
Solaimani S, Bouwman H, Itälä T (2013b) Networked enterprise business model alignment: a case study on smart living. Inf Syst Front. doi:10.1007/s10796-013-9474-1

Tangen S (2004) Performance measurement: from philosophy to practice. Int J Product Perform Manag 53:726-737

Teece DJ (2010) Business models, business, strategy and innovation. Long Range Plan 43:172-194

Tian CH, Ray BK, Lee J, Cao R, Ding W (2008) BEAM: a framework for business ecosystem analysis and modeling. IBM Syst J 47:101-114

Tseng FM, Chiu YJ, Chen JS (2009) Measuring business performance in the high-tech manufacturing industry: a case study of Taiwan's large-sized TFT-LCD panel companies. Omega 37:686-697

Van Aken J, Romme G (2009) Reinventing the future: adding design science to the repertoire of organization and management studies. Organ Manag J 6:5-12

Venkatraman N, Ramanujam V (1986) Measurement of business performance in strategy research: a comparison of approaches. Acad Manag Rev 11:801-814

Verschuren P, Hartog R (2005) Evaluation in design-oriented research. Qual Quant 39:733-762

Voelpel SC, Leibold M, Eckhoff RA (2006) The tyranny of the balanced scorecard in the innovation economy. J Intell Cap 7:43-60

Wirtz BW (2011) Business model management: design-instruments-success factors, 2011th edn. Gabler Verlag, Wiesbaden

Wisner JD, Fawcett SE (1991) Link firm strategy to operating decisions through performance measurement. Prod Inven Manag J 32:5-11

Zott C, Amit R (2008) The fit between product market strategy and business model: implications for firm performance. Strateg Manag J 29:1-26

Zott C, Amit R (2010) Business model design: an activity system perspective. Long Range Plan 43:216-226

Zott C, Amit R, Massa L (2011) The business model: recent developments and future research. J Manag $37: 1019-1042$ 